\title{
Implementasi Model Pembelajaran Terhadap Peningkatan Keterampilan Bermain Bola Voli
}

\section{Implementation of Learning Models for Increasing Volleyball Playing Skills}

\author{
Vicki Ahmad Karisman ${ }^{1}$ \\ 1Program Studi PJKR, Sekolah Tinggi Keguruan dan IImu Pendidikan (STKIP) Pasundan, Jl. \\ Permana No.32 B, Citeureup, Cimahi Utara, Cimahi City, West Java, 40512, Indonesia \\ email: vicki4karisman@gmail.com \\ doi: $\underline{\text { https://doi.org/10.20884/1.paju.2020.2.1.3096 }}$
}

\begin{abstract}
Abstrak
Keterampilan bermain penting dimiliki oleh setiap pemain bola voli. Penguasaan Teknik yang baik tidak cukup untuk menampilkan performa pada saat bermain bola voli. Tujuan penelitian ini adalah untuk mengetahui implemntasi teching games for understanding terhadap keterampilan bermain siswa. Metode penelitian yang digunakan adalah eksperimen dengan pretest and posttest group desain. Populasi penelitian ini adalah siswa Sekolah Menengah Pertama kelas VIII. Teknik sampeling yang digunakan dalam penelitian ini adalah clusterrandom sampling, dengan partisipan sebanyak 48 orang. Instrument yang digunakan untuk mengambil data adalah Games Performance assessment Instrument (GPAI). Penelitian ini dilakukan selama 6 minggu dengan pertemuan sebanyak 12 kali dengan 90 menit setiap pertemuan. Analisis data menggunakan paired samples t-test. Hasil penelitian menunjukan bahwa terdapat pengaruh yang signifikan dari penerapan model Teaching Games for Understanding (TGFU) terhadap keterampilan bermain permainan bola voli. Model TGFU pada praktek dilapangan mengedepankan pendekatan bermain mampu mendorong siswa untuk melakukan berbagai keterampilan bermain bola voli dengan lebih baik. Kesimpulan dari penelitian ini yaitu model TGFU sangat efektif untuk diterapkan dalam pemebelajaran permainan bola voli di SMP. Pada peneltiian selanjutnya, model TGFU dapat diterapkan pada jenjang pendidikan berbeda serta jenis olahraga permainan yang lainnya.
\end{abstract}

Kata Kunci : TGFU, Keterampilan Bermain, Bola Voli

\begin{abstract}
It is Important for every volleyball player to have appropriate skills. Having good technique is not enough to show your performance when playing volleyball. The purpose of this study is to determine the implementation of teaching games for understanding towards the students' playing skills. The researcher used an experiment method with pretest and post-test design groups. The population of this research is the VIII grade junior high school students. The sampling technique used in this study was cluster random sampling, with the participation of 48 people. The instrument used to retrieve data is the Game Performance
\end{abstract}


Assessment Instrument (GPAI). This research was conducted for 6 weeks with 12 meetings with 90 minutes of each meeting. The researcher used paired samples $t$-test for analyzing the data. The results showed a significant influence from the implementation of the Teaching Games for Understanding (TGFU) model toward the skill of playing volleyball. The TGFU model in field practice puts forward a play approach which is able to encourage students to perform various volleyball playing skills better. The conclusion of this study is that the TGFU model is very effective to be applied in learning volleyball games in junior high school. In further research, the TGFU model can be applied to different levels of education and other types of sports.

Keywords : TGFU, playing skills, volleyball.

\section{PENDAHULUAN}

Penguasaan keterampilan kecabangan olahraga perlu dimiliki oleh setiap pelaku olahraga. Keterampilan dalam melakukan Teknik kecabangan khususnya olahraga permainan penting dikuasai. Namun demikian keterampilan teknik yang baik belum menjadi jaminan seseorang untuk dapat melakukan permainan yang sebenarnya. Dalam olahraga permainan seperti bola voli tidak hanya teknik permainan saja yang penting tapi keterampilan bermain sangatlah dibutuhkan. Pembelajaran penjas disekolah seringkali menggunakan pembelajaran langsung (Faozi, Sanusi, \& Listiandi, 2019; Nur et al., 2020). Pembelajaran pendidikan jasmani yang dipusatkan pada model pengajaran langsung menghasilkan tingkat ketidakaktifan murid yang tinggi (Roberts \& Fairclough, 2011). Hal ini menyebabkan menjadikan siswa menjadi fasif.

Permasalahan yang berhubungan dengan tujuan dari kompetensi dasar di dalam kurikulum yang sedang berjalan yang lebih menitikberatkan kepada keterampilan kecabangan olahraga seperti mempraktikkan variasi dan kombinasi teknik dasar berbagai bentuk permainan (Ginanjar, Suherman, Juliantine, \& Hidayat, 2019). Tujuan kompetensi ini menyebabkan keterampilan kecabangan olaharaga lebih dominan. Perlu adanya pendekatan atau model yang lebih memeberikan keleluasaan siswa dalam melakuakan permainan olahraga. Sehingga terjadi keseimbangan antara keterampilan Teknik dan keterampilan bermain. Permasalahan dalam pemebelajaran konvensional, metode pengajaran dominan menerapkan latihan keterampilan dan praktek teknik dalam pendidikan jasmani (Stolz \& Pill, 2014). Keterampilan teknik yang mendominasi seringkali mengabaikan keterampilan dalam bermain khususnya bermain bersama tim. Untuk 
Vicki Ahmad Karisman | Implementasi Model Pembelajaran Terhadap Peningkatan Keterampilan Bermain Bola Voli

melakukan permainan bola voli tidak hanya kemampuan teknik yang dibutuhkan akan tetapi kemampuan bermain.

Keterampilan bermain dapat ditingkatakn melalui permainan sederhana. Siswa didorong untuk memahami keterampilan taktis dan kesadaran taktis melalui permainan yang dapat berupa diskusi kelompok selama permainan berlangsung (Budi, Hidayat, \& Febriani, 2019). Guru mengajukan pertanyaan tentang "apa," "di mana," dan "mengapa," dan bukan hanya "bagaimana." Melalui cara ini diharapakan ada interaksi melalui komunikasi dan implementasi gerakan dalam permainan. Dengan demikian, konsep tersebut telah berubah selama beberapa dekade terakhir. Pendekatan saat ini lebih berpusat pada siswa (student centre), berbasis masalah dan jauh dari pendekatan yang berpusat pada guru (teacher centre) (Tan, Chow, \& Davids, 2012).

Salah satu model pembelajaran yang dapat meningkatakan keterampilan taktis adalah Teaching Games for Understanding (TGFU). Melalui pemebelajaran TGFU siswa dapat ditingkatkan dalam pengambilan keputusan, pelaksanaan teknis, saling mendukung, kinerja permainan, keterlibatan permainan, kesenangan, kompetensi yang dirasakan, dan niat untuk aktif secara fisik setelah implementasi unit TGFU. Siswa dan guru akan merasakan peningkatan pada berbagai variable di atas sebagai hasil dari proses implementasi TGFU (Morales-Belando, Calderón, \& Arias-Estero, 2018). Selain itu, pendekatan permainan menunjukkan bahwa pendekatan taktis permainan dapat meningkatkan perilaku metakognitif di kelas pendidikan jasmani di sekolah dasar (Chatzipanteli, Digelidis, Karatzoglidis, \& Dean, 2016). TGFU berpotensi sebagai model pedagogis yang digunakan untuk mencapai pengembangan keterampilan permainan, baik pengembangan taktis dan motorik (Stolz \& Pill, 2014). Penelitian menunjukan bahwa, pembelajaran yang berfokus pada permainan muncul untuk mempromosikan motivasi melalui tugas yang diberikan . selain itu memiliki potensi untuk meningkatkan motivasi dalam pemebelajaran penjas (Gray, Sproule, \& Morgan, 2009).

Keterampilan bermain dalam pembelajaran permainan jauh lebih komplek. Siswa tidak hanya dituntut mampu melakukan dan mengunakan keterampilan tersebut, tetapi juga harus mengkombinasikan keterampilan dengan orang lain pada kondisi dan situasi yang bisa berubah-ubah, sehingga harus dibutuhkan strategi dan taktik dalam permainan (Susworo, 2006). Kondisi ini kadang membingungkan siswa. Siswa yang memilki tekinik yang bagus belum tentu dapat bermain dengan berbagai situasi. Kebutuhan ini yang 
membuat pembelajaran dengan pendekatan taktis sangat efektif. Mahaiswa dibiasakan untuk senantiasa berada dalam permainan yang komplek dan tidak hanya mempelajari satu teknik saja.

Model TGFU di dahului dengan penekanan pada teknik apa yang digunakan dan kapan dan di mana untuk menggunakannya. Siswa harus didorong untuk melaksanakan strategi atau prinsip main yang menyeluruh seperti penggunaan kedalaman dalam permainan net seperti badminton. Masalah taktis seperti mengatur serangan dengan menciptakan ruang di sisi lawan gawang dapat diatasi dengan efektif atau keterampilan bergerak tanpa bola (Ward \& Griggs, 2011). Untuk itu perlu dilakukan pembelajaran yang mampu mengakomodir keterampilan teknik dan keterampilan taktis dalam permainan. Sehingga penelitian ini menggunakan model Teaching Games for Understanding (TGFU). Peneltiian terdahulu talah banyak mengkaji mengenai penerapan model pembelajaran TGFU di berbagai olahraga permainai seperti sepakbola dan basket. Akan tetapi pada olahraga net game seperti bola voli, model pembelajaran TGFU perlu dikaji lebih mendalam. Selain itu penelitian sebelumnya juga telam membagah mengenai penerapan model TGFU di tingkat sekolah darar dan sekolah menengah atas, sedangkan pada jenjang sekolah menengah pertama perlu adanya peneltiian dengan metode TGFU tersebut.

Model TGFU berpotensi : (1) untuk memfasilitasi pengembangan keterampilan teknis dan pengetahuan taktis; (2) memberdayakan anak-anak untuk belajar sendiri dan bertanggung jawab; (3) untuk menilai transfer taktis di seluruh permainan; dan (4) untuk meningkatkan kesenangan dan kesenangan dalam bermain game (Wang \& Ha, 2012). Berdasarkan beberapa hasil peneltiian terdahulu diatas maka tujuan dari peneltian ini yaitu untuk mengetahui dampak yang diberikan dari model TGFU terhadap keterampilan bermain dalam permainan bola voli.

\section{METODE}

Penelitian ini menggunakan metode eksperimen, dengan pretes and posttest group desain (Fraenkel, Wallen, \& Hyun, 2012). Populasi penelitian ini adalah siswa kelas VIII di SMPN Parongpong. Sampel penlitian sebnyak 48 orang siswa dengan rata-rata usia perempuan ( \pm 14,3 tahun) dan usia laki-laki (14,5 tahun). Teknik pengambilan 
Vicki Ahmad Karisman | Implementasi Model Pembelajaran Terhadap Peningkatan Keterampilan Bermain Bola Voli

sampel menggunakan cluster random sampling.

Instrument yang digunakan untuk mengambil data adalah "Games Performance assessment Instrument (GPAl)" (Memmert \& Harvey, 2010). Instrument ini digunakan untuk mengukur keterampilan bermain siswa. Adapun komponen yang di lihat yaitu sebagai berikut:

Tabel 1. Komponen Permainan yang Diamati di GPAI (Definisi Umum)

\begin{tabular}{ll}
\hline \multicolumn{1}{c}{ Komponen Permainan } & \multicolumn{1}{c}{ Deskripsi } \\
\hline Decision making & $\begin{array}{l}\text { Membuat keputusan yang tepat tentang apa yang harus dilakukan dengan } \\
\text { bola selama pertandingan }\end{array}$ \\
\hline Skill execution & Eksekusi Efisien keterampilan yang dipilih \\
\hline Adjust & Gerakan pemain, baik secara offensive, seperti yang dituntut oleh alur \\
& permainan \\
\hline Cover (Bertahan) & Memberikan dukungan yang tepat, bantuan, serta mendukung kepada \\
& pemain yang sedang memegang bola \\
\hline Support & Memberikan dukungan yang tepat untuk rekan satu tim dengan bola \\
\hline Guard/Mark & dengan berada dalam posisi untuk menerima umpan \\
\hline Base & Kenjaga lawan dengan tepat pada saat bertahan \\
\hline
\end{tabular}

Tabel 2. Definisi Prilaku pada Permainan Bola Voli

\begin{tabular}{|c|c|c|}
\hline Nilai & Rating & Definisi \\
\hline 5 & $\begin{array}{l}\text { Kinerja yang sangat } \\
\text { efektif }\end{array}$ & $\begin{array}{l}\text { Selalu berusaha untuk berbagi; berkomunikasi mendukung kepada } \\
\text { orang dengan atau tanpa bola pada tim. Mampu menempatakan bola } \\
\text { dengan tepat pada saat menyerang dan mampu mendukung teman } \\
\text { satu team pada saat bertahan. }\end{array}$ \\
\hline 4 & Kinerja yang efektif & $\begin{array}{l}\text { Sebagian besar waktu digunakan untuk berbagi: berkomunikasi } \\
\text { mendukung kepada orang dengan atau tanpa bola pada tim. Mampu } \\
\text { menempatakan bola pada saat menyerang dan mampu mendukung } \\
\text { teman satu team pada saat bertahan. }\end{array}$ \\
\hline 3 & Cukup efektif & $\begin{array}{l}\text { Mencoba berkomunikasi dengan tim pada saat bertahan atupun } \\
\text { menyerang. Mencoba memukul dengan baik dan mencoba bertahan } \\
\text { seperlunya. }\end{array}$ \\
\hline 2 & Kinerja rendah & $\begin{array}{l}\text { Jarang berkomunikasi dengan rekan satu tim baik pada saat } \\
\text { menyerang atupun bertahan. Cenderung asal-asalan ketika } \\
\text { melakukan berbagai teknik baik menyerang ataupun bertahan. }\end{array}$ \\
\hline 1 & Kinerja sangat rendah & $\begin{array}{l}\text { Tidak pernah berkomunikasi dengan teman satu tim. Tidak } \\
\text { memperdulikan keadaan team baik saat menjadi menyerang ataupun } \\
\text { bertahan. }\end{array}$ \\
\hline
\end{tabular}


Tabel 3. Penilaian GPAl

\begin{tabular}{|c|c|c|c|}
\hline \multirow[t]{2}{*}{ Nama } & Pengambilan Keputusan & \multicolumn{2}{|c|}{ Pelaksanaan Keterampilan } \\
\hline & TS & $\mathbf{E}$ & TE \\
\hline \multicolumn{4}{|l|}{ Skor mentah } \\
\hline Indeks & $\mathrm{DMI}=\mathrm{S} /(\mathrm{S}+\mathrm{TS})$ & \multicolumn{2}{|c|}{$\mathrm{SEI}=\mathrm{E} /(\mathrm{E}+\mathrm{TE})$} \\
\hline Penampilan Bermain & \multicolumn{3}{|l|}{$\mathrm{PB}=\mathrm{PKt}+\mathrm{PKr} / 2$} \\
\hline Keterlibatan dalam Permainan & \multicolumn{3}{|c|}{$\begin{array}{l}\text { KP = Jumlah semua perilaku yang pantas dan tidak pantas (yaitu, } \\
\text { keputusan yang tepat dibuat }+ \text { keputusan tidak pantas yang dibuat }+ \\
\text { eksekusi keterampilan yang sesuai }+ \text { eksekusi keterampilan yang } \\
\text { tidak pantas) }\end{array}$} \\
\hline
\end{tabular}

Ket :

S : Sesuai

TS : Tidak Sesuai

E : Effective

IE : Tidak effective

PB : Penempilan Bermain

KP : Kererlibatan dalam Permainan

Penelitian ini selain menggunakan instrument GPAI, dalam pengambilan datanya dibantu dengan kamera untuk mengambil video pada saat sample sedang bermain. Kamera ditempatkan pada emapt sudut, sehingga dapat terlihat jelas performa siswanya. Penelitian ini dilakukan selama 6 minggu dengan pertemuan sebanyak 12 kali dengan 90 menit setiap pertemuan. Analisis data menggunakan SPSS dengan menggunakan uji hipotesis paired samples t-test untuk mengetahui pengaruh dari model TGFU terhadap keterampilan bermain bola voli.

HASIL

Data yang diperoleh dari hasil Games Performance assessment Instrument (GPAI) selanjutnya diolah menggunakan SPSS 21 dengan hasil sebagai berikut :

Tabel 4. Paired Samples Test

\begin{tabular}{|c|c|c|c|c|c|c|c|c|c|}
\hline & & \multicolumn{5}{|c|}{ Paired Differences } & & \multirow[b]{3}{*}{$\mathrm{df}$} & \multirow[b]{3}{*}{ Sig. (2-tailed) } \\
\hline & & \multirow[b]{2}{*}{ Mean } & \multirow{2}{*}{$\begin{array}{l}\mathrm{S} \quad \mathrm{td} . \\
\text { Deviation }\end{array}$} & \multirow{2}{*}{$\begin{array}{l}\text { Std. Error } \\
\text { Mean }\end{array}$} & $\begin{array}{l}95 \% \\
\text { Interval } \\
\text { Difference }\end{array}$ & $\begin{array}{l}\text { Confidence } \\
\text { of the }\end{array}$ & & & \\
\hline & & & & & Lower & Upper & $\mathrm{T}$ & & \\
\hline Pair 1 & TGFU & 4.501 & 3.072 & .801 & 3.323 & 4.501 & 8.859 & 5 & .000 \\
\hline
\end{tabular}


Vicki Ahmad Karisman | Implementasi Model Pembelajaran Terhadap Peningkatan Keterampilan Bermain Bola Voli

Tabel paired sample test menunjukan bahwa diperoleh mean sebesar 4,501, yang berarti selisih skor hasil pretest dan posttest implementasi model TGFU terhadap keterampilan bermain bola voli. Selain itu data statistics menunjukan harga statistic $t=8,859$ dengan $d f=5$ dan angka signifikansi atau $p$-value sebesar $0,000<0,05$ atau $\mathrm{H}_{0}$ ditolak. Dengan demikian, berarti terdapat pengaruh yang signifikan dari Teaching Game for Understanding terhadap keterampilan bermain bola voli.

\section{PEMBAHASAN}

Hasil penelitian menunjukan adanya pengaruh yang signifikan dari penerapan TGFU terhadap keterampilan bermain dalam permainan bola voli. Hal ini dapat terjadi karena, TGFU memberikan keleluasaan bagi siswa untuk bermain. TGFU telah menekankan tidak hanya pentingnya taktik tetapi juga cara di mana taktik dipelajari (Qohhar \& Pazriansyah, 2019) . Dari perspektif pedagogis, kita tahu bahwa siswa yang terlibat di tingkat yang lebih tinggi belajar lebih banyak (Butler \& Linda L. Griffin, 2010). Siswa yang diberikan kesemapatan lebih banyak belajar maka akan semakin mampu menguasai taktik dan teknik dalam suatu permainan khususnya dalam penelitian ini permainan bola voli.

siswa dengan pendekatan TGFU dalam berbagai kegiatan dari dua versus dua atau tiga berbanding tiga, para siswa memiliki kesempatan untuk membuat keputusan tentang apa yang harus dilakukan dengan bola (Ray \& Michael, 2011). Dengan demikian siswa akan memiliki banyak kesempatan untuk melakukan dan mengetahui cara yang tepat dalam mengambil keputusan. Dalam permainan, siswa mengamati pemain lain, berpikir tentang taktik, membuat keputusan tentang penggunaan keterampilan olahraga, dan menyelesaikan masalah taktis yang muncul selama pertandingan dengan demikian, TGFU adalah cara yang baik untuk mendorong pemikiran mendalam di kalangan siswa.

Selain itu Kunci keberhasilan TGFU adalah teknik bertanya dan relevansinya dengan siswa tentang pengenalan aturan dan teknik. Fokusnya adalah pada siswa dan pemecahan masalah. Pendekatan pengajaran ini sangat efektif menggunakan pembelajaran aktif di mana siswa belajar melalui permainan (Webb, Pearson, \& Forrest, 2006). Dalam permainan, siswa mengamati pemain lain, berpikir tentang taktik, membuat keputusan tentang penggunaan keterampilan olahraga, dan menyelesaikan masalah taktis 
yang muncul selama pertandingan. Dengan demikian, TGFU adalah cara yang baik untuk mendorong pemikiran mendalam di kalangan peserta didik (Wang \& Ha, 2013).

Tujuan pendekatan berbasis teknik adalah untuk mempelajari pelaksanaan teknis sebelum bermain game, pendekatan TGFU menunjukkan bahwa pemahaman permainan harus diperkenalkan melalui permainan yang dimodifikasi sebelum eksekusi teknis. Ini berarti bahwa untuk berpartisipasi dengan kesadaran, siswa harus secara eksplisit tahu kapan, di mana, dan mengapa menggunakan teknik dalam permainan dan bukan hanya eksekusi teknis belaka (Morales-Belando et al., 2018). Kemudian Pengajaran dengan pendekatan bermain dengan permainan yang dimodifikasi bertujuan untuk memberikan makna serta relevansinya dengan permainan adalah untuk mengembangkan keterampilan dan pada saat yang sama mengembangkan pemahaman (Light, 2012).

Selanjutnya (Ray \& Michael, 2011) yang melaporkan bahwa pendekatan yang berpusat pada permainan dapat membantu siswa untuk memahami, menerapkan, menganalisis dan mengevaluasi tindakan mereka. TGFU merupakan pendekatan dalam pembelajaran pendidikan jasmani terutama permainan yang memungkinkan anak untuk selalu kreatif dan mengerti tentang konsep-konsep bermain. Pendekataan TGFU merupakan salah satu pendekatan yang mengakomodir kebutuhan anak dalam bermain (Saryono \& Soni, 2017). Ini menandakan bahwa pendekatan pembelajaran melalui permainan dalam model TGFU mampu meningkatkan keterampilan siswa khsusunya dalam permainan bola voli. Peningkatakn keterampilan bermain bola voli dapat dilakukan tidak hanya melalui implementasi TGFU saja. Perlu di terapkan juga model lain dalam peningkatan keterampilan bermain bola voli.

\section{SIMPULAN}

Model TGFU merupakan model berbasis permainan. Dalam penelitian ini permainan diberikan melalui permainan bola voli. Berdasarkan analisis dan pengolahan data yang telah dilakukan maka kesimpulan dalam penelitian ini adalah terdapat pengaruh yang signifikan dari penerapan Model Teaching Games for Understanding (TGFU) terhadap keterampilan bermain permainan bola voli. Namun demikian, penelitian ini terbatas pada jumlah sampel yang relatif sedikit. Penelitian di masa yang akan datang diharapakan dapat melibatkan jumlah sampel yang lebih besar dan diharapkan juga dapat 
Vicki Ahmad Karisman | Implementasi Model Pembelajaran Terhadap Peningkatan Keterampilan Bermain Bola Voli

mencari alternative lain dalam meningkatakn keterampilan bermain bola voli khususnya pada tingkat menengah pertama.

\section{REFERENSI}

Budi, D. R., Hidayat, R., \& Febriani, A. R. (2019). The Application of Tactical Approaches in Learning Handballs. JUARA: Jurnal Olahraga. https://doi.org/10.33222/juara.v4i2.534

Butler, J. I., \& Linda L. Griffin. (2010). More Teaching Games for Understanding. In Scott Wikgren (Ed.), Journal of Experimental Psychology: General. United States of America: Human Kinetics.

Chatzipanteli, A., Digelidis, N., Karatzoglidis, C., \& Dean, R. (2016). A tactical-game approach and enhancement of metacognitive behaviour in elementary school students. Physical Education and Sport Pedagogy, 21(2), 169-184. https://doi.org/10.1080/17408989.2014.931366

Faozi, F., Sanusi, H., \& Listiandi, A. D. (2019). Pengaruh Model Pembelajaran Kooperatif Tipe Stad Terhadap Keterampilan Passing Bawah Dalam Permainan Bola Voli Di SMA Islam Al-Fardiyatussa'adah Citepus Palabuhanratu. Physical Activity Journal. https://doi.org/10.20884/1.paju.2019.1.1.2001

Fraenkel, J. R., Wallen, N. E., \& Hyun, H. H. (2012). How to Design and Evaluate Research in Education. In The McGraw-Hill Companies. https://doi.org/10.1017/CB09781107415324.004

Ginanjar, A., Suherman, A., Juliantine, T., \& Hidayat, Y. (2019). Sports orientation during learning team or individual sports using a sport education model. Cakrawala Pendidikan, 38(2), 377-386. https://doi.org/10.21831/cp.v38i2.24021

Gray, S., Sproule, J., \& Morgan, K. (2009). Teaching team invasion games and motivational climate. European Physical Education Review, 15(1), 65-89. https://doi.org/10.1177/1356336X09105212

Light, R. (2012). Game sense: Pedagogy for performance, participation and enjoyment. In Game Sense: Pedagogy for Performance, Participation and Enjoyment. https://doi.org/10.4324/9780203114643

Memmert, D., \& Harvey, S. (2010). Identification of non-specific tactical tasks in invasion games. Physical Education and Sport Pedagogy, 15(3), 287-305. https://doi.org/10.1080/17408980903273121

Morales-Belando, M. T., Calderón, A., \& Arias-Estero, J. L. (2018). Improvement in game performance and adherence after an aligned TGfU floorball unit in physical education. Physical Education and Sport Pedagogy, 0(0), 1-15. https://doi.org/10.1080/17408989.2018.1530747

Nur, L., Malik, A. A., Juditya, S., Kastrena, E., Widyawan, D., Agustan, B., ... Yang, C. B. (2020). Comparison of two types of instruction in physical education. International 
Journal of Psychosocial Rehabilitation. https://doi.org/10.37200/IJPR/V24I10/PR300205

Qohhar, W., \& Pazriansyah, D. (2019). Pengaruh Model Pembelajaran Kooperatif Tipe Teaching Games For Understanding (TGFU) Terhadap Peningkatan Hasil Belajar Teknik Dasar Sepakbola. Physical Activity Journal, 1(1), 27-35. https://doi.org/doi:10.32424/1.paju.2019.1.1.1998

Ray, B., \& Michael, S. (2011). Developing Game Sense Through Tactical Learning: A Resource for Teachers and Coaches. New York, NY: Cambrige University Press.

Roberts, S., \& Fairclough, S. (2011). Observational analysis of student activity modes, lesson contexts and teacher interactions during games classes in high school (1116 years) physical education. European Physical Education Review, 17(2), 255-268. https://doi.org/10.1177/1356336X11420222

Saryono, \& Soni, N. (2017). Gagasan Dan Konsep Dasar Teaching Games for Understanding (TGFU). 9(6B), 199. https://doi.org/10.12681/icodl.1145

Stolz, S., \& Pill, S. (2014). Teaching games and sport for understanding: Exploring and reconsidering its relevance in physical education. European Physical Education Review, 20(1), 36-71. https://doi.org/10.1177/1356336X13496001

Susworo, A. (2006). Acuan Pembelajaran Permainan Softball Model TGfU. Jurnal Pendidikan Jasmani Indonesia, 5(2).

Tan, C. W. K., Chow, J. Y., \& Davids, K. (2012). "How does TGfU work?": Examining the relationship between learning design in TGfU and a nonlinear pedagogy. Physical Education and Sport Pedagogy, 17(4), 331-348. https://doi.org/10.1080/17408989.2011.582486

Wang, L., \& Ha, A. S. (2012). Factors influencing pre-service teachers' perception of teaching games for understanding: A constructivist perspective. Sport, Education and Society, 17(2), 261-280. https://doi.org/10.1080/13573322.2011.607954

Wang, L., \& Ha, A. S. (2013). Three groups of teachers' views, learning experiences, and understandings of teaching games for understanding. Physical Education and Sport Pedagogy, 18(3), 336-350. https://doi.org/10.1080/17408989.2012.666789

Ward, G., \& Griggs, G. (2011). Principles of Play: A proposed framework towards a holistic overview of games in primary physical education. Education 3-13, 39(5), 499-516. https://doi.org/10.1080/03004279.2010.480945

Webb, P. I., Pearson, P. J., \& Forrest, G. (2006). Teaching Games for Understanding ( TGf $U$ ) in primary and secondary physical education. ICHPER-SD International Conference for Health, Physical Education, Recreation, Sport and Dance, 1st Oceanic Congress, Wellington, New Zealand, (October), 1-4. https://doi.org/10.1111/j.1551-2916.2008.02556.x 